Original Article

\title{
Sleep and rest needs of seniors: a study grounded in the work of Henderson*
}

\author{
Necessidades relacionadas ao sono/ repouso de idosos: estudo fundamentado em Henderson
}

Necesidades relacionadas al sueño/ reposo de ancianos: estudio fundamentado en Henderson

\author{
Jorge Wilker Bezerra Clares ${ }^{1}$, Maria Célia de Freitas², Francisca Tereza de Galiza ${ }^{3}$, \\ Paulo César de Almeida ${ }^{4}$
}

\begin{abstract}
Objective: To identify the sleep/rest needs of an elderly population cared for by the Family Health Strategy, based on Virginia Henderson's theoretical framework. Method: This descriptive, quantitative study was conducted from May to June, 2011 through the application of a questionnaire to 52 seniors living in an area covered by a Primary Health Care (PHC) unit in Fortaleza, CE, Brazil. The data were analyzed using statistical software. Results: the sleep disorders most frequently reported by the seniors were: sleeping less than four hours a night (84.6\%), daytime sleepiness (71.2\%), nighttime awakenings (71.2\%), and the use of sleep medications (21.2\%). Association was significant in relation to the variables: age $(p=0.05)$, morbidities $(p=0.02)$, smoking $(p=0.01)$, and pain when moving $(p=0.05)$. Conclusion: The sleep/rest needs of seniors were significantly associated with socio-economic factors and health conditions.
\end{abstract}

Descriptors: Aged; Sleep; Needs Assessment

\section{RESUMO}

Objetivo: Analisar as demandas de necessidades relacionadas ao sono/repouso de uma população idosa no âmbito da Estratégia Saúde da Família, fundamentada no referencial de Virgínia Henderson. Métodos: Estudo de abordagem quantitativa, descritivo, realizado entre maio e junho de 2011, mediante aplicação de formulário a 52 idosos residentes na área coberta por uma unidade básica de saúde de Fortaleza-CE. Os dados foram analisados por meio de software estatístico. Resultados: Os problemas de sono mais comum entre os idosos foram: dormir menos de 4 horas por noite $(84,6 \%)$, sonolência diurna $(71,2 \%)$, despertares noturnos $(71,2 \%)$, uso de medicamentos para dormir $(21,2 \%)$. A análise de associação mostrou-se significativa com as variáveis, idade $(\mathrm{p}=0,05)$, presença de morbidade $(\mathrm{p}=0,02)$, tabagismo $(\mathrm{p}=0,01)$ e dor ao mover-se $(p=0,05)$. Conclusão: As demandas para a necessidade de dormir/repousar nos idosos estiveram associadas significativamente a fatores socioeconômicos e condições de saúde.

Descritores: Idoso; Sono; Determinação de necessidades de cuidados de saúde

\section{RESUMEN}

Objetivo: Analizar las demandas de necesidades relacionadas al sueño/reposo de una población anciana en el ámbito de la Estrategia Salud de la Familia, fundamentada en el referencial de Virginia Henderson. Métodos: Estudio de abordaje cuantitativo, descriptivo, realizado entre mayo y junio del 2011, mediante la aplicación de un formulario a 52 ancianos residentes en el área cubierta por una unidad básica de salud de Fortaleza-CE. Los datos fueron analizados por medio de un software estadístico. Resultados: Los problemas de sueño más comunes entre los ancianos fueron: dormir menos de 4 horas por noche $(84,6 \%)$, somnolencia diurna $(71,2 \%)$, despertares nocturnos $(71,2 \%)$, uso de medicamentos para dormir $(21,2 \%)$. El análisis de asociación se mostró significativo con las variables, edad $(\mathrm{p}=0,05)$, presencia de morbilidad ( $\mathrm{p}=0,02)$, tabaquismo $(p=0,01)$ y dolor al moverse $(p=0,05)$. Conclusión: Las demandas para la necesidad de dormir/reposar en los ancianos estuvieron asociados significativamente a factores socioeconómicos y condiciones de salud.

Descriptores: Anciano; Sueño; Evaluación de necesidades

\footnotetext{
* Paper extracted from the final paper presented to the undergraduate nursing program at the State University of Ceara titled "Elderly's health needs within primary bealth care: a study grounded in Virginia Henderson”, 2011. Fortaleza (CE), Brazil.

${ }^{1}$ Master's student, Graduate Program in Clinical Practice in Nursing and Health Care, State University of Ceará - UECE. Member of the Research Group in Nursing, Education, Health and Society - GRUPEESS. Fortaleza (CE), Brazil.

${ }^{2}$ PhD in Fundamentals of Nursing. Professor, Undergraduate Nursing Program and Graduate Program in Clinical Practice in Nursing and Health Care, State University of Ceará - UECE. Member of the Research Group in Nursing, Education, Health and Society - GRUPEESS. Fortaleza (CE), Brazil.

${ }^{3}$ MSc in Clinical Practice in Health. Professor, Undergraduate Nursing Program, Federal University of Piaui - UFPI. Member of the Research Group in Nursing, Education, Health and Society - GRUPEESS. Fortaleza (CE), Brazil.

${ }^{4}$ PhD in Public Health. Undergraduate Nursing Program and Graduate Program in Clinical Practice in Nursing and Health Care, State University of CearáUECE. Assistant-director of the Research Group in Nursing, Education, Health and Society - GRUPEESS. Fortaleza (CE), Brazil.
} 


\section{INTRODUCTION}

Sleep is considered a basic human need and one of the factors that influences the quality of life of human beings. Among seniors, however, sleep needs are frequently harmed ${ }^{(1,2)}$. The aging process changes an individual's quantity and quality of sleep, affecting more than half of the seniors living in the community and $70 \%$ of institutionalized individuals, causing a negative impact on quality of life. One study conducted with seniors living in the community verified that sleep deprivation was present in $30.6 \%$ of the sample and disturbed sleep patterns in $88 \%$ of the studied individuals ${ }^{(3.4)}$.

These changes in sleep/rest patterns alter one's homeostatic balance, with repercussions on the psychological function, immunological system, performance, behavioral response, mood, and ability to adapt ${ }^{(3.5)}$.

Poor quality sleep, as well as sleep disorders, results in difficult to concentrate; reduced response speed; loss of memory, concentration and performance; difficulty maintaining good family and social relationships; increased incidence of pain; tendency to poorly evaluate one's own health; reduced ability to perform daily tasks; increased use of health services and decreased survival. Among seniors, these signs may be considered changes accruing from the aging process or interpreted as an indication of cognitive impairment or dementia ${ }^{(6)}$.

In this context, health workers should be attentive to the problems presented by the elderly and be qualified to diagnose and intervene in the event of physiological changes, chronic diseases, and geriatric syndromes as well as heeding other factors that negatively interfere in their daily life, seeking to solve and/or control these factors. Therefore, health workers should consider the implications of poor quality sleep for the routine and health of seniors, observing its potential to impair the quality of life of this population.

Understanding that primary health care, provided through the Family Health Strategy (FHS), is the entry door of users into the Brazilian health system and is a privileged space to provide integral healthcare to the elderly ${ }^{(7)}$, we consider essential that health workers, especially nurses, reflect upon the reality experienced by this population in the family and community context. Therefore, nurses can plan innovative interventions, grounded on technology and science, seeking to meet the needs of seniors.

There are many nursing theories that can ground the actions of nurses, which professionals should know to select the one that best heeds the needs of elderly individuals according to their context and from an integral perspective. In this study we use Virginia Henderson's theoretical framework, which proposes an analysis in which the individual is unique and complex, enabling an approach to seniors from an individual and integral perspective. Over the course of her work, this theorist identified and listed 14 basic needs that encompass biological, psychological, sociological, cultural and spiritual aspects, essential for human beings to maintain and/or recover health. These needs represent the components of nursing care, functions exclusive to nurses, and can be described as: breathing, eating, elimination, movement, sleep and rest, clothes, body temperature, hygiene, environmental control, communication, religious practices, work, leisure, and learning. These components do not represent the shortcomings or weaknesses of human beings, but are intrinsic events, and when lacking them, human beings require care to recover them and regain independence ${ }^{(1)}$.

From this perspective, acquiring knowledge concerning the health needs of seniors represents the possibility to improve nursing care provided to this segment of the population, in order to promote their functional capacity, preserving autonomy and independence. Upgrading knowledge concerning these needs can support improvement in the practice of health workers, especially of nurses, as well as their ability to identify, manage, and prevent changes in seniors at the level of the FHS. Therefore, this study can contribute to the planning of educational actions directed to the nursing staff and other health workers with a view to minimize sleep/rest problems among seniors, promoting the quality of life of this population.

Giving the preceding discussion, this study's objective was to identify the sleep/rest needs of an elderly population cared for by the Family Health Strategy under Virginia Henderson's theoretical framework.

\section{METHOD}

This is a descriptive, cross-sectional study with a quantitative approach. The population was composed of seniors living in two micro areas covered by a primary health care unit in Fortaleza, CE, Brazil, a region where courses in the health field, from the State University of Ceará, develop teaching, research and extension activities. Inclusion criteria were: being 60 years old or older; living in the micro areas previously selected; being physically and mentally sound to answer the questions. Seniors not found at home after three attempts were excluded. Of the 61 seniors identified in the records presented by the health community agents, 52 met the criteria and composed the final sample.

Data were collected in the seniors' homes between May and June 2011. The data collection instrument was a form composed of closed questions, the organization and structure of which were based on Henderson's 
theoretical framework ${ }^{(1)}$.

Information was collected about the individuals' socio-economic and health status (age, gender, marital status, education, religion, occupation, family income, presence of morbidity) addressing the 14 basic human needs. Questions concerning sleep and rest needs were analyzed in this study from the perspective of seniors cared for within the primary health care. Specifically in relation to this need, the questions addressed the presence of sleep disorders, use of sleep medications; frequency of night awakenings and difficulty resuming sleep; daytime sleepiness; intake of caffeine/stimulants; whether they had a peaceful environment in which to sleep, and the need for help to fall sleep and rest.

The study project was approved by the Institutional Review Board at the Dr. Carlos Alberto Studart Gomes - Messejana Hospital (Process No. 97/10). The City Health System Coordination, an organ of the City Health Department of Fortaleza, also authorized the study. All ethical guidelines regulating research with human subjects were complied with, in accordance with Resolution 196/96. Data collection was initiated after the participant/guardian signed free and informed consent forms.

The results were processed and tabulated using the Statistical Package for the Social Sciences, version 17.0. For data analysis, we opted for descriptive statistics, absolute and percentage frequency tables. Associations among categorical variables were analyzed through the Chi-square test. The level of significance was fixed at $5 \%(\mathrm{p} \leq 0.05)$.

\section{RESULTS}

In regard to socio-demographic characterization, $36(69.2 \%)$ interviewees were women and $16(30.8 \%)$ were men, with an average age of $72.6 \pm 8.6$ years, ranging from 60 to 92 years old. In terms of education, $29(55.8 \%)$ reported not having completed primary education and $17(32.7 \%)$ were illiterate. In regard to their marital statuses, $25(48.1 \%)$ were married and $21(40.4 \%)$ were widowed. As for income, 36 (69.3\%) were retired, although, eight (15.3\%) seniors still maintained paid jobs, among them, sewing and trade. Most $(50 / 96.2 \%)$ seniors reported income below three times the minimum wage (Table 1 ).

The main problems related to rest/sleep needs reported by the participants were: sleeping less than 4 hours a night, 44 (84.6\%); daytime sleepiness, 37 (71.2\%); frequent night awakenings, 37 (71.2\%); not having a peaceful place in which to sleep, $12(23.1 \%)$; and the use of sleep medication, $11(21.2 \%)$.

Associations between the socio-demographic variables and sleep disorders did not show significant differences, with the exception of the variable age, indicating that older seniors had more difficulty falling and remaining asleep $(\mathrm{p}=0.05)$ (Table 1).

Table 1. Prevalence of sleep disorders in seniors cared for by the primary health care according to socio-demographic and clinical characteristics and health habits. Fortaleza, CE, Brazil 2011.

\begin{tabular}{|c|c|c|c|}
\hline Variables & $\mathrm{n}(\%)$ & $\begin{array}{c}\text { Sleep } \\
\text { disorders } \\
(\%)\end{array}$ & P-value \\
\hline \multicolumn{4}{|l|}{ Gender } \\
\hline Male & $16(30.8)$ & 13.5 & \multirow[t]{2}{*}{0.25} \\
\hline Female & $36(69.2)$ & 40.4 & \\
\hline \multicolumn{4}{|l|}{ Age (in years) } \\
\hline $60-69$ & $17(32.7)$ & 15.4 & \multirow{3}{*}{$0.05^{*}$} \\
\hline $70-79$ & $20(38.5)$ & 15.4 & \\
\hline 80 year old or older & $15(28.8)$ & 23.0 & \\
\hline \multicolumn{4}{|l|}{ Marital Status } \\
\hline Married/stable union & $25(48.1)$ & 19.2 & \multirow{4}{*}{0.26} \\
\hline Widowed & $21(40.4)$ & 26.9 & \\
\hline Separated/divorced & $04(7.7)$ & 5.7 & \\
\hline Single & $02(3.8)$ & 1.9 & \\
\hline
\end{tabular}

Education

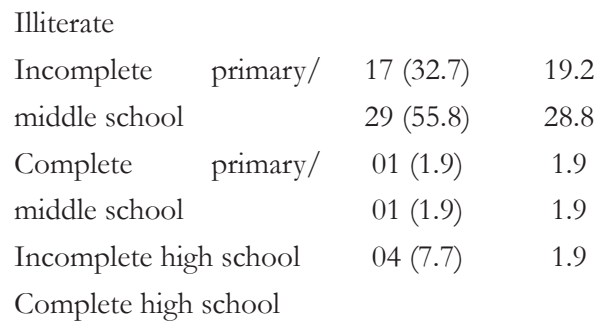

Income (times minimum wage)

Up to 3

$50(96.2) \quad 50.0$

0.28

4 or more

$02(3.8) \quad 3.8$

Occupation

Retired

$36(69.2) \quad 32.9$

0.51

Other

$16(30.8)$

21.1

Morbidities

$\begin{array}{cccc}\text { Yes } & 42(80.8) & 30.8 & 0.02^{*} \\ \text { No } & 10(19.2) & 3.8 & \end{array}$

Smoking

$\begin{array}{llll}\text { Yes } & 33(63.5) & 43.2 & 0.01^{*} \\ \text { No } & 19(36.5) & 11.5 & \end{array}$

Pain when moving

\begin{tabular}{llll} 
Yes & $29(55.8)$ & 36.5 & $0.05^{*}$ \\
No & $23(44.2)$ & 17.3 & \\
\hline
\end{tabular}

*Statistically significant with $\mathrm{p} \leq 0.05$ 
In relation to self-reported health status, the participants mentioned that morbidities were the cause of their sleep/rest disorders because they were a source of concern. The following stand out among the diseases reported: hypertension, 25 (48.1\%); osteoporosis, 18 (34.2\%); alcoholism, 11 (21.2\%); diabetes, 10 (19.2\%); gastritis, 8 (15.4\%); and urinary incontinence, 8 (15.3\%). Other morbidities were less frequently reported, such as rheumatism, arthritis, arthrosis, depression, heart failure, chronic renal failure, Parkinson's disease and Alzheimer's disease.

A statistically significant association was found between the presence of morbidities and sleep disorders $(\mathrm{p}=0.02)$. We verified that smokers reported more sleep disorders when compared to non-smokers $(p=0.01)$. Pain when moving was also reported as a factor that interfered in quality of sleep $(\mathrm{p}=0.05)$ (Table 1$)$.

More than half of the studied seniors, $37(71.2 \%)$, consumed large quantities of coffee and/or stimulants such as colas. Despite the various problems interfering or possibly interfering in these individuals' ability to fall asleep and/or remain asleep, only nine (17.3\%) seniors reported the need for help to meet their sleep and rest needs.

\section{DISCUSSION}

The advent of population aging requires health workers to understand the complexity of the human's aging process, how to strengthen individual and integral care provided to seniors, and the development of new practices and care actions in health. In this context, experiencing the family and social context of seniors is a way to observe other dimensions of health care and implement actions that meet local needs in accordance with the proposals of the FHS.

Investigating aspects related to sleep and rest needs from the perspective of seniors reflects a search for integral care provided to this growing population that demands specific care due to the vulnerability and fragility that result from advanced age. From this perspective, evaluating the sleep patterns of this population is essential for professionals practicing within the scope of the FHS to plan health interventions, taking into account the impact of such conditions on seniors' quality of life.

A change in sleep patterns is expected among seniors, resulting in frequent complaints concerning difficulties falling asleep. In this study, sleep disorders were present in $27(51.9 \%)$ seniors. The results indicate that people require greater attention as age advances, observing the increase in reports of sleep-related problems. In this sense, older seniors presented more sleep disorders that younger seniors $(\mathrm{p}=0.05)$.
The greater proportion of sleep disorders among seniors may be associated with chronic diseases, the frequency of which increases in this age group. Corroborating this hypothesis, the relationship between sleep disorders and the presence of morbidities showed significant association $(p=0.02)$ among the study's participants. Among the problems identified in this population, cough and respiratory problems, aggravated by smoking, and pain that results from osteoarticular problems, were statistically significant with sleep disorders ( $\mathrm{p}=0.01$ and $\mathrm{p}=0.05$ respectively), that is, smoking seniors and those reporting pain had more difficulty sleeping.

Sleep disorders can be the cause as well as a consequence of diseases ${ }^{(1)}$; thus, chronic health conditions impose a series of limitations that can change human responses involving sleep/rest such as: therapeutic scheme, physical discomfort, and threats to life. In this manner, living with a chronic disease is a significant factor reducing the quantity and quality of sleep, consequently, harming the quality of life of seniors.

The high percentage of sleep disorders found among the studied seniors may also be related to the intake of caffeine by this share of the population. Even though no statistical associations were found, the intake of these substances was high among $37(71.2 \%)$ seniors. The use of caffeine derivatives and stimulants can harm sleep patterns in the elderly, since caffeine increases latency and decreases efficiency in sleep, time in stage 2 and the total hours of sleep ${ }^{(8)}$.

Additionally, not having a calm environment to sleep due to noise, people sharing the same bedroom with the senior, too much light in the room, and other factors, may hinder and even impede the seniors' sleep/rest ${ }^{(1,9)}$. Concerning this aspect, we observed the presence of pubs and taverns near the studied areas that remain open much of the night, generating a noisy environment surrounding the seniors' homes. It results in sudden changes in sleep and wakefulness habits, harming this population's quality of sleep and making it a chronic and complex problem.

As a consequence of this environment, night awakenings were frequent complaints, reported by 37 $(71.2 \%)$ seniors. The authors note that fragmented sleep results in reduced total hours of sleep and non-restorative sleep ${ }^{(2)}$. In this context, daytime sleepiness, reported by $37(71.2 \%)$ participants, may be a result of insufficient night sleep.

We also note that $11(21.2 \%)$ seniors reported the use of sleep medication, corresponding to an expressive percentage considering the risks inherent to its use. A study conducted with seniors living in outlying neighborhoods in the city of Fortaleza, CE, Brazil reports an even higher percentage of the permanent use of this 
type of medication $(29.4 \%)^{(10)}$. This phenomenon may be a response to difficulties in falling and remaining asleep, especially during the night.

The use of this type of medication by seniors should be investigated during nursing consultations since the chronic use of these drugs does not impede the onset of other sleep problems and can also cause undesirable effects to seniors' health and quality of life ${ }^{(11)}$. Hence, these drugs should be prescribed with caution, taking into account both the benefits and side effects, the origin of the sleep disorder and, in particular, the patient's age $e^{(12)}$.

Despite the various sleep and rest problems reported by this population, the fact that most $(43 / 82.7 \%)$ report no need for help to meet these needs draws attention. This high prevalence may be a result from a difficulty in realizing that poor sleep may interfere in daily life and harm a person's health and quality of life. Additionally, it is possible that many seniors consider their problems to be a natural and inevitable consequence of the aging process.

Seniors generally report their complaints related to sleep, but many do not perceive it as a dysfunction; rather these needs are seen as a normal event of the aging process. This contributes to underdiagnosis and increases the use of hypnotic drugs, not always prescribed and used considering age-related pharmacodynamics sensitivity ${ }^{(3)}$.

Given the context presented in this study, it is essential that health workers be qualified to perceive the persistence of the aging process in seniors and become sensitive to the limitations and peculiarities of these individuals, seeking to better understand the physical, emotional and social changes that take place at this age.

Workers from the multidisciplinary health team, practicing within the scope of the primary health care, need to develop interconnected actions seeking to promote the health of aging individuals. The objective is to prevent physical, mental and social impairment while at the same time devising alternatives to promote the rehabilitation of those who already experience some degree of dependence.

In this context, we stress the role of nurses in identifying health needs, planning, implementing and evaluating interventions to improve the quality of life of seniors living in the community to which they deliver care. Nurses should be attentive to the complaints of users and be prepared to intervene preventively and therapeutically, according to individual needs.

Therefore, there is a need for nurses to assess sleep patterns during nursing consultations, considering the impact of problems resulting from these unmet needs in the routine of seniors. Even though sleep-related complaints are common among individuals of advanced age, these complaints should be assessed and seen as demands, whether they are a consequence of aging or are characterized as organic or psychiatric illnesses. The onset or aggravation of these conditions can be prevented if given the proper importance, investigated and made subject to intervention.

From this perspective, we suggest judicious assessment of sleep/rest patterns and related demands, supporting the planning of nursing interventions to improve the quality of life for seniors living in the community through the delivery of integral healthcare. Non-drug measures aimed to enable better quality of life, particularly, during old age, should be considered. Even though these changes affect productivity and sleep duration, elderly individuals considered to be healthy maintain their ability to sleep and restore functional energy.

We consider this study to be an awakening for issues related to the context of seniors living in the community, a reflection to better understand the problem experienced by this population. It will enable the development and planning of health actions directed to the specific needs of this group according to a new model of health care that takes into account the different aspects influencing the health-disease continuum, resulting in integral and contextualized care.

It is however necessary to take into consideration that the results obtained reflect a specific context, since this study addressed a population living in the areas covered by a single primary health care unit. Nevertheless, the methodology used can be replicated in studies addressing distinct contexts, enabling generalizations, seeking to obtain safer and more concrete bases for the development of strategies and the delivery of integral healthcare to people experiencing the aging process.

\section{CONCLUSION}

This study's findings reveal that the variables age, morbidity, smoking, and pain when moving are statistically associated with problems that interfere in the satisfaction of sleep/rest needs among seniors living in the area covered by the FHS in Fortaleza, CE, Brazil. These results are an important source of information concerning the health needs of seniors and can support the delivery of integral healthcare to this population within the scope of primary health care and can also be a motivation for future research. 


\section{REFERENCES}

1. Henderson V. Principios fundamentales de los cuidados de enfermería. Bol Oficina Sanit Panam. 1958;44(3):217-40.

2. Araújo CL, Ceolim MF. Sleep quality of elders living in long-term care institutions. Rev Esc Enferm USP. 2010;44(3):615-22.

3. Geib LT, Cataldo Neto A, Wainberg R, Nunes ML. Sleep and aging. Rev Psiquiatr Rio Gd Sul. 2003;25(3):453-65.

4. Araújo LA, Bachion MM. [Nursing diagnoses of the Pattern of Mobility in the elderly attended by the Family Health Program]. Rev Esc Enferm USP. 2005;39(1):53-61. Portuguese.

5. Alessi AC, Schnelle JF. Approach to sleep disorders in the nursing home setting. Sleep Med Rev. 2000;4(1):45-56.

6. Alessi CA, Martin JL, Webber AP, Cynthia Kim E, Harker JO, Josephson KR. Randomized, controlled trial of a nonpharmacological intervention to improve abnormal sleep/wake patterns in nursing home residents. J Am Geriatr Soc. 2005;53(5):803-10.

7. Oliveira JC, Tavares DM. Elderly attention to health strategy in the family: action of nurses. Rev Esc Enferm USP. 2010;44(3):763-70.

8. Quinhones MS, Gomes MM. [Sleep in normal and pathological ageing: clinical and physiopathological aspects]. Rev Bras Neurol. 2011;47(1):31-42. Portuguese.

9. Marosti CA, Dantas RA. [Assessment of stressors among inpatients of a coronary] Care Unit. Acta Paul Enferm. 2006;19(2):190-5.Portuguese.

10. Silva MJ, Lopes MV, Araújo MF, Moraes GL. [Level of independence in activities of daily life in low-income elderly from Fortaleza - Ceará]. Acta Paul Enferm. 2006;19(2):201-6. Portuguese.

11. Costa SV, Ceolim MF, Neri AL. Sleep problems and social support: Frailty in a Brazilian Elderly Multicenter Study. Rev Latinoam Enferm. 2011;19(4):920-7.

12. Voyer P, Verreault R, Mengue PN, Morin CM. Prevalence of insomnia and its associated factors in elderly long-term care residents. Arch Gerontol Geriatr. 2006;42(1):1-20. 